\title{
Philosophy and Psychology in the Styles of Architecture and Environmental Design of the Late 19th- 21st Centuries
}

\author{
Marina E. Vengerova ${ }^{1, *}$ \\ ${ }^{1}$ Higher School of Environment Design, Moscow Institute of Architecture (State Academy), Moscow, Russia \\ "Corresponding author. Email: archteor@gmail.com
}

\begin{abstract}
Within the framework of training programs at the Moscow Institute of Architecture (State Academy), the tasks of brief illumination and explanation of the system of changing architectural and design styles of XIX-XXI centuries are set. Ignace Meyerson (1888-1983) in his writings showed that the work of creativity is a reflection of the psychology of the author. This statement formed the basis for choosing the angle of view, under which it was decided to consider a variety of stylistic trends. Namely, various psychological approaches, such as practicalism, laconism and "romantic dreams", have allowed us to systematize many trends of the last century and a half to three groups. This simplified systematization allows students to easily use them in their project activities. The division into three groups reveals the deep meanings of the psychological and philosophical foundations, to formulate the goals and tasks facing the architect, designer and customer.
\end{abstract}

Keywords: Styles of architecture, Design, Philosophy, Psychology, Functionalism, Conciseness, Futurism.

\section{INTRODUCTION}

In the architecture of the late nineteenth and early twenty-first centuries, there were many trends that were even manifestations of one great style from the point of view of philosophy, had their own names in each country, for example, Art Nouveau, and also differed in the elements used, as in the eclecticism of the late nineteenth century, where they distinguished the neo-Russian style, neoGothic, Neo-Byzantine, and so on. In modern times, we may actually see a synthesis of different styles in their philosophical approaches, forms, ideas which use generic names, for example, the entire post-modernism, since the sixties of the twentieth century, called postmodernism, and a non-linear architecture that was built using indirect angles. If students at an architectural institute, including the design of the architectural environment, are taught the styles of the late nineteenth and early twentieth centuries as a "kaleidoscope", a set of disparate facts without systematic analysis, they will not be able to understand them. Understand the cause-andeffect relationships and, accordingly, use them in your professional activities, as well as understand the newly emerging trends. Therefore, the pedagogical task of systematizing the recent past of architecture and design for understanding the meanings and application in mixing and "quoting" in creative activity arose.

\section{PHILOSOPHY AND PSYCHOLOGY OF ARCHITECTURAL AND DESIGN STYLES}

The first thing that we consider with the audience is the reflection in the architectural styles of the philosophy of a particular time period [1]. At the same time, both the classical approach to creating architecture of buildings and interiors and the non-classical approach still exist today, since in addition to general social issues and trends, there is the personality of the author and the customer, who design "for themselves" and bring individuality to their creation. This was written by Ignace Meyerson in his scientific qualification work-a dissertation for the degree of Doctor of Philology, 
supported in 1948 [2]. The French historical science of the first half of the twentieth century tended to analyze precisely human experiences in order to characterize certain historical epochs [3], and not to dwell only on the analysis of political or class vicissitudes.

So, if we translate the understanding of classical philosophy into the language of architecture and environmental design, then we get the creation of an ideal space once and for all, in an ideal form, which does not involve regular changes. While buildings or interiors built in a non-classical worldview suggest variability throughout their existence. It turns out that the classical approach and the non-classical approach are still alive and coexist in architecture at the same time.

\section{THREE PSYCHOLOGICAL AREAS OF MODERN STYLES OF ARCHITECTURE: THE SIMPLICITY, PRACTICALITY AND "ROMANTIC DREAMS"}

Based on the arguments of Ignace Meyerson, we can talk about the psychological tracing paper of those involved in project activities. Hence it turns out that after the "official" refusal of society to believe in God, at the level of the psychology of individuals, this feeling that the world can be created in an ideal form, remained in architectural creativity. This is nothing more than the desire to search for ideal shapes and proportions in buildings. This trend can be called laconism, which in the era of modernism we know as rationalism, developed by the architect and teacher of Higher Art and Technical Workshops (VKHUTEMAS) Nikolai Ladovsky. We see the continuation of this in the present, for example, in minimalism and neomodernism.

The opposite direction, which was also voiced in the era of the birth of modernism, was called functionalism. That is, buildings that are dominated not by an ideal form, but by "life" itself, overgrown with walls. What was developed in the twentieth and twenty-first centuries, and turned into a "sustainable" architecture, where the main thing is the preservation of resources and economic feasibility. To the same direction, such practicality, we would also refer to the loft, in which they do not destroy existing buildings, but give them a new life, or the use of secondary resources in the construction of used pallets for bricks, glass or plastic bottles filled with garbage. Multi-functional planning solutions that allow adapting architectural spaces for different tasks and using existing natural landscapes as part of the structure could also be considered in this direction. For example, a house on the side of a mountain, where one wall already exists, or Apple offices, which are often built underground, using it as insulation and constructive.

Both the above-mentioned directions of laconism and practicality psychologically relate to the "real" world: here and now. We are in the present moment, to save resources, or creating a perfect shape. At the same time, architects and customers are also characterized by a subconscious desire to "paradise worlds": either the distant past, where we were kicked out, or the beautiful future, where we will get after this life, or, at least, on vacation in the near future. This desire in creativity also originates at the beginning of the twentieth century, called futurism with its steam locomotives and machines of the future; or an eclectic longing for the past, where "I have never been", at the end of the nineteenth century, manifested by the styles of historicism. Therefore, we would call this psychological direction in creativity "romantic dreams", which would allow us to combine both the craving for the historical past, where we were not, and the future, and for holidays. In the styles of the twentieth century, the appeal to the past in the architecture of the West has been observed since the sixties and was called postmodernism. This is again turning "face" to the history of mankind, its culture, drawing inspiration from them. As well as aspirations for the future - this is high-tech, which appeared after the beginning of space exploration; futurism and parametric architecture, so reminiscent of spaceships, which is especially evident in the design proposals of the Chinese architect Ma Yansong from the Beijing bureau of MAD for the Lucas Museum of Narrative Art commissioned by George Lucas. So, in the project made for Los Angeles, we see the space station as a picture from "Star Wars" of the director, who organizes this museum together with his wife Mellody Hobson, who also works in the film industry as producer. The structure, merging with the clouds, becomes part of the sky, reflecting the bright sun with the purest floating surfaces, hovering above the ground, which is achieved by reducing the building area on the supports and the arrangement of the garden on the roof of the building and the park at its base.

Thus, we are faced with a systematization of architectural and design styles based on human 
psychology, where there are three vectors: laconism, practicality and "romantic dreams".

\section{4. "PRACTICALITY" AND "LACONISM"}

The students and I begin our consideration of the above-mentioned areas of architectural and design creativity with practicality, since this is the most understandable aspiration for people who are beginning to get acquainted with the profession. We discuss that for the construction of buildings for a plant or factory, the main thing is the sequence and dimension of the workshops for the correct logistics of the technological chain, and the architectural shell is only a utilitarian necessity to comply with temperature and humidity conditions.

Analyzing the work of the Soviet architect Konstantin Melnikov (1890-1974), we find out that one architect can work in different directions, depending on the order. So, the club for workers of the tram park, named after the revolutionary communist Ivan Rusakov, built in 1929, is a vivid example of a functional approach to architecture. Where the scheme of using the premises was developed, and then the shell of the necessary and sufficient volumes was built. In the private house of K. Melnikov we have the opposite approach to design - first determines the shape of the building in plan, as the two woven wedding bands, and only then considers the operation of dwellings, resulting in a calculated height of the cylinder, the larger of which has a diameter and greater height, crowned with the workshop of the architect. This shows an anthropomorphic perception of the gender difference between husband and wife, the building itself was a wedding gift to the architect's wife.

In the architecture of the twenty-first century, a practical approach can be observed, for example, in the reconstruction of the Stanislavsky electric Theater on Tverskaya Street in Moscow (20132014). The concept of the director Boris Yukhananov was visualized and implemented by the architects of the Moscow bureau WoWHaus Dmitry Likin, Oleg Shapiro and Mikhail Kozlov [4]. The architects proposed to clear the old walls from the subsequent layers, reinforced them with metal structures and created a multifunctional "filling" of both the interiors and the surrounding area. This is a reflection of the non-classical philosophy, which tells us that everything changes and the architectural space must be ready for functional changes. I would especially like to draw attention to the system of using expensive and cheap finishing materials in this project, which was thought out by Dmitry Likin. Here the architect applied the principle that he himself uses in the design of television studios in the Ostankino television center in Moscow, being the main artist of the First Television Channel for more than ten years. The essence of this technique is that the so-called viewpoints that fall into the frame, or in the field of view of the visitor, are initially determined if the interiors are designed. They are made using expensive materials, and what is far from the views - from the cheap. In the case of the foyer of the Stanislavsky Electrotheater - it is a grand staircase lined with copper sheets that shine like a precious box, while the ceiling is only utilitarily painted.

The same practical approach is observed in the secondary use of previously constructed industrial buildings. An example of a building designed for maximum resource conservation, which is called "sustainable architecture", in the Moscow region is the Hypercube in the Russian Innovation Center "Skolkovo" by the Russian architect Boris Bernasconi, built in 2012. This is the first building in Russia to receive international certification according to the Leadership in Energy and Environmental Design (LEED) standard [5]. In the Hypercube in Skolkovo, the facade of the building is of particular interest. It seems to be gone, and instead of the facade - construction loess, covered with mesh. The architects explain this by the expediency of saving money in the future. Because everything that is being done now is in the elements of architecture or in the design of the architectural environment, in five to ten years will seem outdated. Therefore, in the future, builders will not need to dismantle the obsolete facade, but will only need to remove the grid.

Explaining to students how laconism has remained almost unchanged for almost a hundred years, we consider the work of the architect Mies Van Der Rohe: the German pavilion for the international exhibition in Barcelona in 1929. Then, we turn to a residential building built in Los Angeles, California in 2018 by the architectural bureau AUX Architecture [6]. It is surprising how much the unity of the images of these two buildings is felt. Only a greater amount of artificial light and an ecological theme is added, with the use of vertical and roof landscaping and ikebana.

From the form goes in their design solutions of the Apple sales offices and Norman Foster [7], [8]. So, as a basis, N. Foster takes the appearance of Apple products, for example, a Mac Mini or a smart 
speaker, and so on, and in its form creates entrance pavilions or light lanterns, placing the function itself underground. Thus, we observe the duality of the approaches of practicality and laconism. An example of such a dual approach in creating an architecture is also evident in the design of buildings and planning of the new campus in Cupertino, where respect for the surrounding landscape, how to take care of natural resources with a perfectly shaped circle.

\section{5. "ROMANTIC DREAMS"}

For how long, it is natural for a person to dream of better worlds and better places: "It is good where we are not!". The architects and their customers sometimes tried to restore the old times in their idealized perception in their buildings, just as the reenactors of historical events sew clothes, restore the tools of chivalric or Napoleonic times, playing a fairy tale. Or the gaze in search of a better world rushes to the future, to look at least a little bit where there are no problems of today's world.

In architectural styles, the first part of the memories of those times in which you yourself were not, is associated with the historicism and eclecticism of the late nineteenth century, when buildings were built, in the architectural design of which quotes from buildings of historical times were used, such as Gothic, Old Russian, Old Byzantine, Moorish and others. In the sixties of the twentieth century-this is the program voiced by Philip Johnson: "You cannot not know the history!". After that, he and other architects build buildings in the architecture of which there are replicas and reinterpretations of classical, Gothic, and Renaissance forms. Thus was completed the tower of Philip Johnson's AT\&T, now owned by Sony (1978-82) in New York City in the United States, or a newly erected office skyscraper with turrets and stylized Gothic portals for PPG in Pittsburgh, Pennsylvania in the United States (architects Philip Johnson, John Burgee, 1981-84), and a three-stage skyscraper inspired by Renaissance architecture in northern Europe, originally named the RepublicBank Center in Houston in the United States (architects Philip Johnson, John Burgee, 1980-83).

Or space-related futurism - a flying saucer in the image of the Museum of Modern Art in Niteroi, Brazil, by architect Oscar Niemeyer, built in 19911996. Which seems to have landed on the shore of the oceanic Gulf of Guanabara, it can be seen from afar with a background consisting of rough tropical vegetation and mountain ranges. An ornate red path leads to the building, climbing up which you find yourself at the columnar stand of the bowl-shaped main volume, which is reflected from the artificial pond at the base of the structure, the reflections in which merge with the blue ocean surface create an amazing unearthly feeling of dissolution, soaring and relaxation. Interiors of structures like spaceships of the future are found both in Oscar Niemeyer and in Zaha Hadid's architecture, for example, Dongdaemun Design Plaza in South Korea (2011). The entire building is a hidden Godzilla-a mythical amphibian of the eastern region, which, fitting into the surrounding landscape of a building site in Seoul in South Korea, then rises up, then merges with the earth's surface. The hinged panels create a curved outline of the enclosing structures with partial illumination. The interiors are also striking in their fantastique, combining white glowing glossy surfaces with brutal concrete, from which "falling" vertical supports and floor coverings are made.

We can mention computer-visualizing structures, both in the building of the Berlin Congress Center by architect Ralf Schuehler (19751979), and the image of a punch card, both in the Headquarters of Fuji Television (1996) in Odaiba in Tokyo, by architect Kenzō Tange in addition to the High-tech buildings described above.

\section{CONCLUSION}

Summarizing all of the above, we can conclude that from the point of view of psychology or spiritual aspirations, a person has various aspirations that guide both the creativity of architects and designers, and the desires of customers. We distinguish three vectors: practicality, laconism and "romantic dreams". At the same time, we draw attention to the fact that practicality and laconism are, as it were, creativity "here and now", in the present, while the term "romantic dreams" introduced by us first of all immerses the creator and the audience in the worlds "where we are not", we introduce a kind of generalization of the ideal idea of those spaces, since, unfortunately, people often imagine that it will be good for them, in some other world, and this can be measured in the time scale. For example, in an idealized view of the past, as people tend to forget all the bad and remember only the good, especially if these are historical times, the creator chooses those aspects of the past that he currently benefits or likes. Accordingly, the vector of time 
can be directed to the future, in which no one has been, so you can draw it in your imagination ideal, the way we would like it to be, or the vector of a close moment in time, for example, a vacation that has recently been or is about to come. When a person breaks out of the daily routine, he also remains in a state of rest and rests from problems.

I would also like to draw attention to the fact that when we introduce the directions of practicality, laconism and "romantic dreams", we mean that in real design activities, by analogy with geometry and physics, vectors can be the sum of several original ones, and this is what we mention when talking about our proposed classification of architectural styles, both existing and newly emerging, which in fact can be composite, including particles of large directions that we have analyzed in this article. Our approach to creative activity in terms of the philosophy of augmented psychology allows students to easily navigate the choice of images to meet the requirements of the customer in commercial orders, as well as in individual implementation in non-commercial architecture. Also, this systematization allows you to understand the psychological aspirations of architects, designers and customers when creating works of architecture and environmental design, and to reduce all the variety of architectural and design styles of the late nineteenth and early twenty-first centuries to three groups, which is useful at the beginning of learning the profession.

\section{AUTHORS' CONTRIBUTIONS}

This paper is independently completed by Marina Vengerova.

\section{REFERENCES}

[1] N.G. Popova, History and Philosophy of Science (Architecture): program: textbook for graduate students in the following specialties 05.23.20, 05.23.21, 05.23.22 (Istoriya i filosofiya nauki (arhitektury): programma: uchebnoe posobie dlya aspirantov po special'nostyam 05.23.20, 05.23.21, 05.23.22). Moscow, Moscow Institute of Architecture (State Academy), 2013, 80 p. [in Russian]

[2] I. Meyerson, Les fonctions psychologiques et les oeuvres. Paris, 1948 (Editions Albin Michel, S.A., 1995), 294 p.

[3] F. Ghica, De quelques questins que la psychologie historique d'Ignace Meyerson actualize en psychologie, in: Lafosensu. Revue de la societe de philosophie des sciences. Vol 5 № 1, 2018. Paris, Societe de Philosophie des sciences (SPS), 2018. pp. 6068.

DOI:

http://dx.doi.org/10.20416/lsrsps.v5i1.9

[4] Stanislavsky Electrotheatre, in: Wowhaus. Available at: https://www.archdaily.com/770308/stanislavs ky-electrotheatre-wowhaus

[5] B. Bernaskoni, Hypercube. First building of the Skolkovo innovation center. Available at: http://bernaskoni.com/projects/hypercubebuild ing

[6] AUX Architecture. CROFT RESIDENCE. Available at: https://auxarchitecture.com/projects/croftresidence/

[7] M.E. Vengerova, Brand identity in architecture philosophy and materials, in: New ideas of the New century: materials of the international scientific conference FAD TOGU (Firmennyj stil' v arhitekture: filosofiya i materialy, in: Novye idei novogo veka: materialy mezhdunarodnoj nauchnoj konferencii FAD TOGU). Khabarovsk, Pacific State University, 2019. Tom. 1. pp. 53-68. Available https://elibrary.ru/item.asp?id=37383033

[8] M.E. Vengerova, Branding Identity in Architecture: Christian Churches of Ancient Russia, Hindu Temples of India, and Company Offices of the 21st Century, in: Proceedings of the 2019 International Conference on Architecture: Heritage, Traditions and Innovations (AHTI 2019). Atlantis Press. Advances in Social Science, Education and Humanities Research, volume 324. Paris, June 2019. Pp. 65-72. DOI: https://doi.org/10.2991/ahti-19.2019.15 